\title{
DGFs Årsmøde 2008 - spcendende nyt fra polarforskningen
}

\section{Af geolog Morten L. Hjuler, GeologiskNyt}

En spændende foredragsrække med fokus på polarforskning samt en rekordstor tilslutning på over 100 deltagere gjorde DGF's årsmøde 2008 til en sikker succes.

Lørdag d. 23. februar løb det årligt tilbagevendende årsmøde i Danmarks Geologiske Forening af stabelen på Geocenteret i København. Heldagsarrangementet startede kl. 10.00 og bød på en veltilrettelagt og yderst velpræsenteret foredragsrække, efterfulgt af en flot postersession og en ganske underholdende generalforsamling. En lang spændende dag afsluttedes med festmiddag og uddeling af Danmarks Geologipris 2007.

\section{Med polarforskning som tema}

Foredragsrækken var baseret på forskellige temaer inden for polarforskning, og foredragene knyttede sig derfor fortrinsvist til de arktiske områder, især Grønland.

På Grønland trækker indlandsisen og gletscherne sig tilbage, og havisen skrumper, hvilket har vakt opsigt og ikke mindst bekymring i lyset af den verserende debat om klimaforandringer. Foredragene søgte at belyse de klimatiske konsekvenser af disse forandringer, bl.a. ved kortlægning af klimavariationer i Prækambrium og nyere geologisk tid, samt ved detaljerede undersøgelser af glaciologiske fænomeners dynamik og

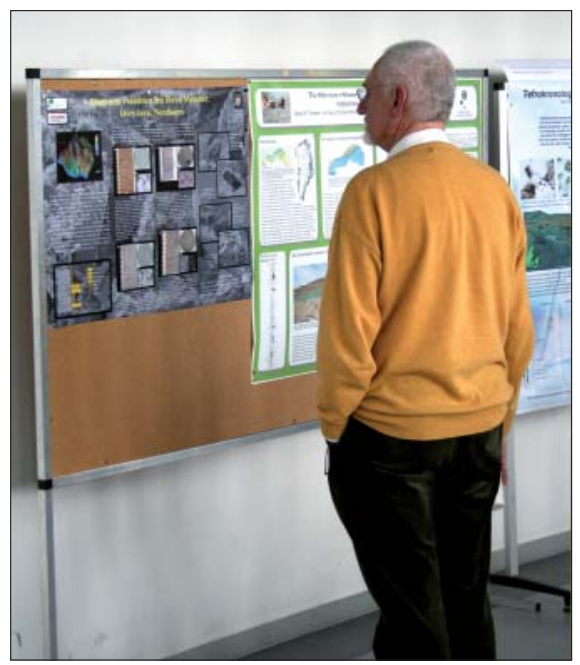

De mange posters blev ivrigt studeret. (Foto: Forfatteren)

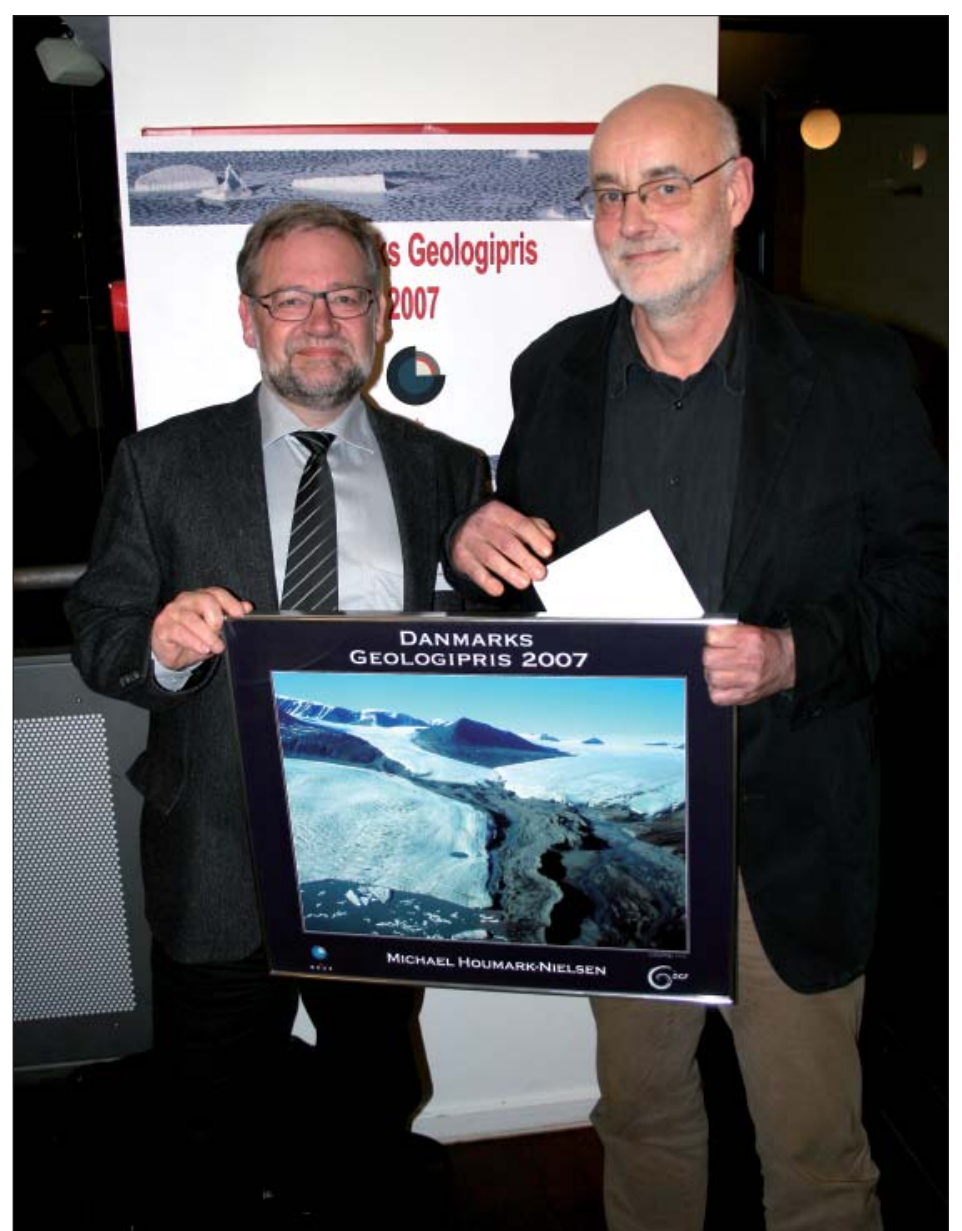

Johnny Fredericia, GEUS, overrakker Michael Houmark-Nielsen (til højre) Danmarks Geologipris 2007. (Foto: Forfatteren)

respons på geologiske og astrofysiske aktiviteter.

Samlet set giver de præsenterede studier et fint indblik i polarforskningens aktive projekter og øjeblikkelige status, og med forskningens relevans in mente kunne man måske overveje at sammenskrive og offentliggøre resultaterne som et bidrag til øget forståelse af klimaforandringernes årsager?

\section{Danmarks Geologipris 2007}

Efter foredragsrækkens afslutning benyttede mange deltagere lejligheden til en nærmere granskning af de mange interessante posters, som præsenterede speciale- og ph.d.studerendes forskningsarbejde. Andre fik diskuteret løst og fast med en skummende, økologisk fadøl i hånden. Som indledning til generalforsamlingen blev præmien for bedste poster uddelt, og æren tilfaldt Mette
Olivarius for hendes spændende poster om det jyske sands oprindelse.

Sidste punkt på dagsordenen var festmiddag kl. 19.00, hvor selskabet blev dygtigt trakteret med dejlig mad, argentinsk "dinosaur-vin" og den festlige bippen fra alarmen, som gik i gang, hver gang kok og tjenere bar frem.

Under festlighederne blev Danmarks Geologipris 2007 overrakt til Michael Houmark-Nielsen for hans fremragende indsats med at anskueliggøre betydningen af Kvartærtidens istidslag i Danmark.

Omkring midnat var den lange, spændende dag i geologiens navn så småt ved at finde sin afslutning, og de opstemte, men trætte festdeltagere kunne begive sig mod hjemmet og en lang nat i selskab med gletscherjordskælv, galopperende gletchere og Jorden som snebold. 